\title{
Examining alliance management capabilities in university-industry collaboration
}

\author{
Alexander Leischnig ${ }^{1} \cdot$ Anja Geigenmüller $^{2}$ \\ Published online: 26 June 2018 \\ (c) The Author(s) 2018
}

\begin{abstract}
Effective university-industry technology transfer requires universities to maintain and strengthen research and technology capabilities on the one hand, but also to develop and strengthen management capabilities to build and manage relationships with external partners on the other hand. This research seeks to advance the knowledge on university-industry collaboration by examining how managerial routines that in sum reflect the concept of alliance management capability influence success of outward university technology transfer. The results of an empirical study with academics from different universities in Germany offer insights into net effects and configurational effects of routines to manage interorganizational collaboration on technology transfer success. The findings indicate that academic units' alliance management capability has a significant positive effect on technology transfer success. In addition, the findings indicate different configurations of alliance management routines, reflecting alternative, consistently sufficient pathways to technology transfer success. This knowledge contributes to current debates by disclosing important predictors of successful university-industry collaboration. In addition, it informs decision makers in universities about how to configure management systems to govern outward technology transfer activity.
\end{abstract}

Keywords Alliance management capability · University-industry collaboration · Technology transfer $\cdot$ FsQCA

JEL Classification $\mathrm{I} 23 \cdot \mathrm{M} 10 \cdot \mathrm{O} 32$

Alexander Leischnig

a.leischnig@qmul.ac.uk

Anja Geigenmüller

anja.geigenmueller@tu-ilmenau.de

1 School of Business and Management, Queen Mary University of London, Mile End Road, London E1 4NS, UK

2 Department of Marketing, Ilmenau University of Technology, Langewiesener Strasse 22, 98693 Ilmenau, Germany 


\section{Introduction}

Technology transfer and knowledge commercialization have become strategic priorities for many universities. Embracing the idea of the "entrepreneurial university", institutions in the higher education sector increasingly strive to manage intellectual properties for commercial purposes and build and maintain relationships with external partners. Revenues from patents, licensing agreements, or spin-offs are becoming an important part of university funding and, at the same time, a key indicator for universities' research productivity (D’Este and Perkmann 2011; Göktepe-Hulten and Mahagaonkar 2010). In addition, policy makers install programs to enforce technology transfer and knowledge commercialization as means to increase social returns from publicly funded research (D'Este and Perkmann 2011; Friedman and Silberman 2003; Perkmann et al. 2013). Cross-national programs such as "Horizon 2020" by the European Commission or the "OECD Innovation Strategy" underline the idea of collaboration between the public and the private sectors to enhance innovation and generate jobs, growth, and a better quality of life (European Commission 2011; OECD 2010).

Within this context, prior work has pointed to the importance of effective universityindustry collaboration as a mechanism to increase the application of university knowledge in business practice (Cyert and Goodman 1997; D'Este and Perkmann 2011; Schartinger et al. 2002). Although university-industry collaboration can provide several opportunities for both universities and firms, it can confront decision makers, especially within universities, with major managerial challenges that are attributable to the diverse nature and the dynamics inherent to many university-industry interactions and prevalent organizational characteristics (e.g., Azagra-Caro et al. 2017; Perkmann and Walsh 2007). Universityindustry collaboration entails the bridging of scholarly and commercial logics (Tartari and Breschi 2012; Villani et al. 2017). Initiating, maintaining, and further developing collaborations with external partners require advanced managerial capabilities not only at the top level of universities, but also at the level of academic units and even individual researchers (Bruneel et al. 2010; Etzkowitz 2004; Etzkowitz et al. 2000). As Ambos et al. (2008, p. 1425 ) point out, "the challenge essentially involves taking an organization that is equipped for and accustomed to doing one thing (academic research) and at the same time asking it to build a capacity for doing something entirely different (commercialization of technologies and ideas)." Academic units oftentimes need to act as firm-like entities (i.e., "quasi firms"), "lacking only a direct profit motive to make them a company" (Etzkowitz 2003, p. 111).

The objective of our article is to further illuminate the role of managerial capabilities of academic units to achieve effective university-industry technology transfers. Specifically, we seek to explicate whether and how alliance management capability contributes to technology transfer success. We conceptualize alliance management capability as a set of organizational routines that enable an organization to manage exchange processes with external partners (Anand and Khanna 2000; Wang and Rajagopalan 2015). Prior work on interfirm collaboration indicates that the capacity to manage alliances enhances the quality of interactions between collaborating partners and increases the likeliness of alliance success (Leischnig et al. 2014; Schreiner et al. 2009). Hence, the presence of routines and capabilities to manage interorganizational relationships should enable academic units to cope with the challenges inherent to university-industry technology transfer and contribute to effective collaboration. The development of such a capability, however, can come with serious costs that arise from devising new resources and/or reconfiguring existing resources 
(Schilke 2014). Moreover, academic units typically differ in their resource endowments and their abilities to develop and strengthen capabilities beyond those that are essential for performing primary teaching and research tasks. Thus, the questions of whether and how alliance management capability contributes to effective outward technology transfer warrant inquiry not only from a theoretical, but also an operational perspective.

In order to answer these questions, we conducted an empirical study with a sample of 85 respondents from different universities in Germany. We performed a two-step, mixedmethod approach to analyze the data, using structural equation modeling (SEM) and fuzzyset Qualitative Comparative Analysis (fsQCA) (e.g., Leischnig et al. 2016). Through SEM we seek to provide insights into the net effects of alliance management capability (and its underlying routines) on technology transfer success. Through fsQCA we seek to offer insights into configurations of routines sufficient for successful technology transfer. While the analysis of net effects deepens the understanding of the impact of one or multiple antecedents on the outcome of interest across the empirical cases under investigation, the analysis of configurational effects helps better understand how multiple antecedents work together and combine into configurations that indicate an outcome consistently.

The findings of our analyses make three important contributions to the literature. First, our research advances extant knowledge by transferring the concept of alliance management capability to the university context, by highlighting its role as a critical capacity of academic units, and by explaining its implications for technology transfer success. Our research thus advances knowledge on technology transfer activity by providing insights into academic-industry collaboration as a mechanism that transcends those conceptualized in the traditional model of university technology transfer, in which technology transfer is conceptualized as a rather formal and linear sequence of processes that starts with a new discovery made by a researcher and that ends with its adoption in industry practice, and in which technology transfer offices (TTOs) have essential roles and authority (Bradley et al. 2013). Second, our article contributes to the literature by performing an in-depth analysis of the effects of alliance management capability on technology transfer success and by delineating net effects and configurational effects. The analysis of net effects indicates cross-case tendencies about how the overall capability and its underlying routines relate to technology transfer success and shows, for example, that academic units' overall capacity to manage relationships with technology transfer partners has a significant positive effect on technology transfer success. The analysis of configurational effects complements these findings by describing different combinations of academic units' alliance management routines and organizational characteristics that indicate successful technology transfer. For example, the findings reveal that the combination of high alliance proactiveness, alliance transformation, interorganizational coordination, and interorganizational learning is one sufficient pathway for successful technology transfer, irrespective of academic units' particular organizational structure. Besides this configuration, however, further consistently sufficient factor combinations exist. These combinations vary in their particular composition but they all indicate technology transfer success, thus providing vision for complementarity effects among managerial routines and organizational attributes of academic units that contribute to technology transfer success. Related to this point, and from a methodological perspective, our article makes a third contribution by illustrating how the combination of variable-oriented methods, such as SEM, and more case-oriented methods, such as fsQCA, helps obtain fine-grained insights into phenomena of interest. Responding to recent calls that advocate a paradigm shift in theory-crafting and testing (e.g., Woodside 2013; 2014) and that emphasize the configurational approach as an inquiring systems to better understand alliance management (e.g., Geigenmüller and Leischnig 2017), we demonstrate 
how fsQCA can complement the insights obtained by SEM to deepen the understanding of university-industry collaboration.

We organize the remainder of this article as follows. In the next section, we present the conceptual background and the research framework of this study. We then outline the research approach used to test our research framework and we present the results of the study. Our article concludes with the discussion of findings, theoretical contributions, and managerial implications.

\section{Conceptual background and research framework}

Technology transfer is the managed process of conveying technologies, technological ideas, or know-how from a developing to an adopting party, such as, for example, from a university to a commercial entity (Friedman and Silberman 2003; Schoenecker et al. 1989; Souder et al. 1990). Prior work indicates different modes of technology transfer and reveals more formal approaches, such as collaborative research or contract research, as well as more informal approaches, such as the provision of advice or networking (D'Este and Patel 2007; Meyer-Krahmer and Schmoch 1998; Perkmann 2015; Perkmann and Walsh 2008; Perkmann et al. 2013).

Two major reasons underline the need for a purposeful and goal-oriented management of university-industry technology transfer. First, the integration of technology transfer into a university's repertoire of academic functions usually requires cultural shifts and changes in mindset not only at the level of the university, but also at the level of the individual researcher (Etzkowitz 1998; Tartari and Breschi 2012). Researchers and academic units need managerial as well as entrepreneurial orientations, skills, and capacities to interact with external partners effectively (Jain et al. 2009; Meyer 2003). Second, the formation of alliances between universities and external partners presupposes that the organizations involved agree upon goals of the collaboration, grant access to resources, learn from each other, and, eventually, generate benefits for both sides. However, differences in organizational structures, norms, and regulations, as well as different expectations regarding the transfer process, time frames, and outcomes frequently exist (Chandran et al. 2015; Perkmann et al. 2011).

Within this context, prior work in the strategic management literature points to an organization's alliance management capability as an important antecedent of (alliance) performance outcomes (Pateli and Lioukas 2012; Schilke and Goerzen 2010). The organizational capability to manage alliances has been shown to contribute to more structured and coordinated interactions between alliance partners, more seamless and efficient exchanges, and more effective transfer processes (Heide and John 1990; Lambe et al. 2002; Leischnig et al. 2014). It can be conceived as a dynamic capability to purposefully create, extend, or modify an organization's resource base, augmented to include the resources of its alliance partners (Helfat et al. 2007; Schilke and Goerzen 2010) and represents the focal antecedent factor in our research framework (Fig. 1).

The framework includes two models (i.e., a net effects model and a configurational effects model) to symbolize the analytical steps used to delineate the relationships between alliance management capability and technology transfer success. Building on conceptual (Dyer and Singh 1998) and empirical work on alliance management (Kale et al. 2002; Schilke and Goerzen 2010), we conceptualize alliance management capability as a multifaceted construct that consists of four components, namely alliance 
(a)

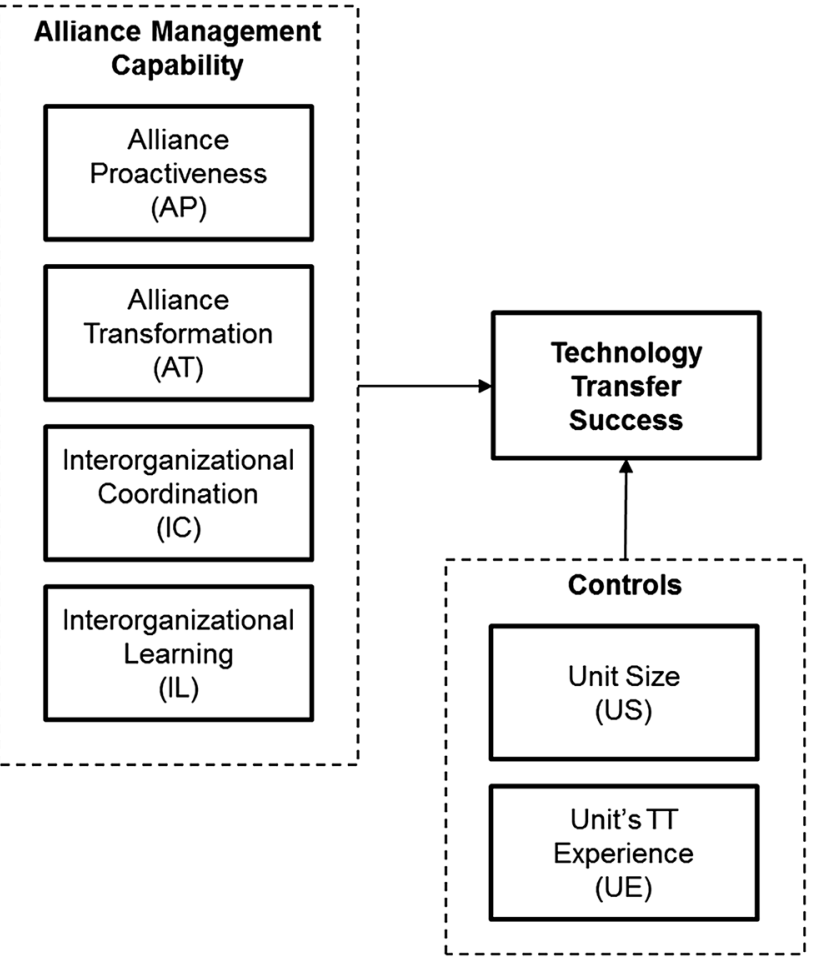

(b)

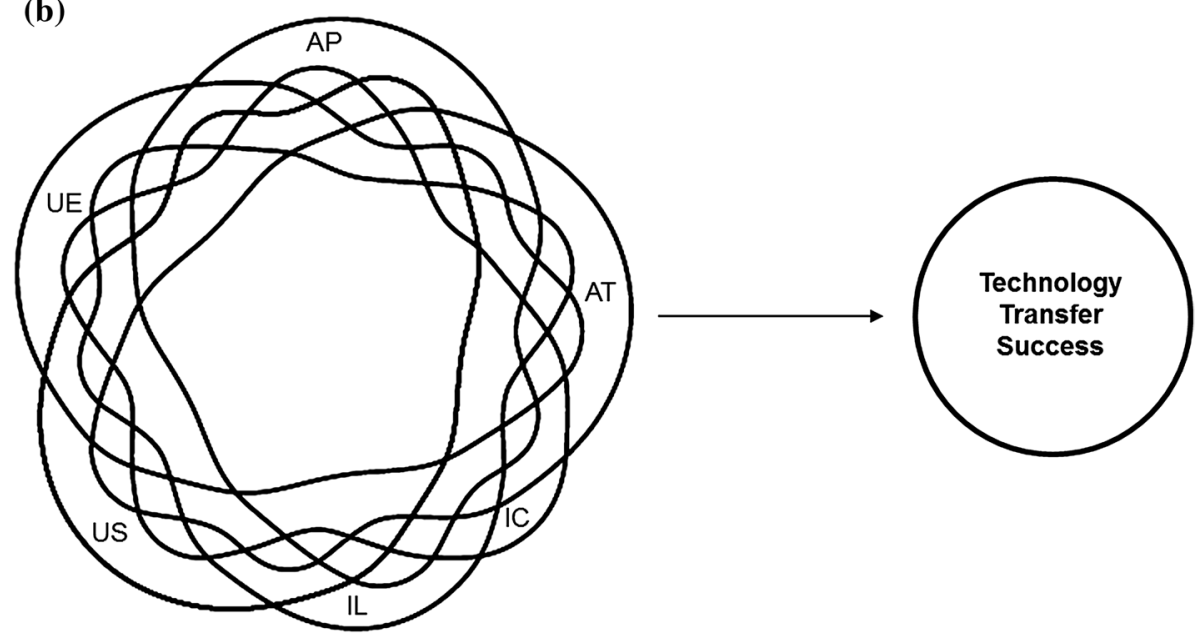

Fig. 1 Net effects model and configurational effects model of alliance management capability and technology transfer success. a Net effects model, b configurational effects model 
proactiveness, alliance transformation, interorganizational coordination and interorganizational learning. Alliance proactiveness refers to the "efforts to identify potentially valuable partnering opportunities" (Sarkar et al. 2001, p. 702). In a general sense, alliance proactiveness enables the identification of market requirements and new opportunities, which represents an important capacity to achieve high market performance in different contexts (e.g., Leischnig and Geigenmüller 2018). An alliance-proactive academic unit may identify new opportunities for technology transfer by scanning the industrial environment (e.g., to detect potentially relevant recipient firms for a new technology) and take preemptive action in response to the opportunity (Lumpkin and Dess 1996). Alliance transformation refers to the flexibility of a transfer partner to adapt the transfer process in reacting to changed conditions (Reuer and Zollo 2000). Although universityindustry collaborations may aim for perfect fit and seamless interactions, such states are rarely achieved from the beginning. Hence, adjustments such as contractual amendments or adaptations in collaboration-related governance mechanisms may be needed to ensure an effective and efficient transfer of technology (Reuer and Zollo 2000). Interorganizational coordination is a further facet of alliance management capability and pertains to the governance of individual alliances. According to Schreiner et al. (2009, p. 1401), interorganizational coordination aims to "identify and build consensus about task requirements in a given alliance, the nature of the associated interdependence between partners, and the specification of working procedures for task execution." Interorganizational coordination ensures an efficient governance of processes and greater transaction legitimacy among partners (Kumar and Nti 1998). Finally, interorganizational learning refers to the ability to acquire and utilize knowledge throughout the collaboration (Lane and Lubatkin 1998). It allows for improvements of knowledge bases regarding industry partners and characteristics of university-industry interactions.

The baseline hypothesis of our article is that an academic unit's alliance management capability should contribute to technology transfer success. Studies indicate that technology transfer success can have several meanings (Bozeman 2000), which implies the need for a clear specification of the conceptual domain of our outcome condition. Following prior research, which mentions that measures of performance for interorganizational relationships should reflect the mutual benefit that emerges for both partners (Bucklin and Sengupta 1993; Van de Ven 1976), we define technology transfer success as the perceived performance of the bilateral interorganizational relationship between the technology transferor (i.e., the academic unit) and the technology transferee (i.e., the firm). This conceptualization covers the extent to which the partners in a technology transfer project show commitment toward the relationship between them and assess this relationship as productive and worthwhile (Bucklin and Sengupta 1993; Leischnig et al. 2014). The basic premise underlying the anticipated positive effect of alliance management capability on technology transfer success is that the existence of predefined routines and rules to manage interorganizational processes that extend beyond unit boundaries, will lead to more smooth interactions with external partners and benefits for both partners. This notion is backed up by prior research assessing value creation and success in strategic alliances (Kale et al. 2002) and by prior research on R\&D alliances, which has shown that alliance management capability has a positive impact on alliance performance (Schilke and Goerzen 2010). Technology transferors with well-established alliance management capabilities can better initiate, implement, and govern transfer processes with their capacity to alter the resource base as required to achieve desired outcomes in bilateral interorganizational relationships. This notion finds further support by prior research on inward technology transfer. For example, Leischnig et al. (2014) show that a technology transferee's alliance management capability 
has a positive impact on interaction quality in interorganizational technology transfers, which in turn leads to successful technology transfers.

\section{Research approach}

\subsection{Sample and data collection}

To examine the relationship between alliance management capability and technology transfer success, we conducted an empirical study including a cross-disciplinary online survey with key informants from multiple universities in Germany. The sampling frame consisted of a listing of 618 informants covering two primary disciplines: engineering science and materials science. These disciplines typically engage in prolific technology research, show high levels of technology expertise and know-how, as well as high technology commercialization activity. Key informants of the academic units (i.e., professors, senior researchers, and researchers) were contacted to participate in the online survey. The respondents received a cover letter inviting their participation, along with the link to the online questionnaire. The cover letter indicated that no correct or wrong answers existed and that the data were collected anonymously. In total, 85 respondents participated in the survey, yielding a response rate of $14 \%$. A comparison of responses between early and late respondents did not reveal any significant differences (all $p>.05$; Armstrong and Overton 1977). Table 1 details the sample composition.

\subsection{Questionnaire development}

A standardized questionnaire served as the main data collection instrument. We used multi-item measures from Schilke and Goerzen's (2010) scale to capture the four components of alliance management capability. In addition, we used five items from Bucklin and Sengupta (1993) to measure technology transfer success. Respondents provided answers

Table 1 Sample composition

\begin{tabular}{lc}
\hline Sample characteristics & Percent \\
\hline Disciplines & 57 \\
Engineering sciences & 43 \\
Materials sciences & \\
Unit size (number of members) & 9 \\
$1-5$ & 14 \\
$5-10$ & 17 \\
$10-20$ & 34 \\
$20-50$ & 26 \\
More than 50 & \\
Position of respondents & 67 \\
Professor (head of department) & 15 \\
Senior researcher (project leader) & 18 \\
Researcher & \\
\hline
\end{tabular}


for these constructs on five-point Likert-type agreement scales anchored in "fully disagree" and "fully agree."

Besides these construct measures, we captured controls. We measured the size of the academic unit and its prior experience with conducting technology transfer projects. The size of an organizational unit influences its ability to specialize and assign (human) resources to execute (alliance-related) tasks (e.g., Kale and Singh 2007; Schreiner et al. 2009). In addition, prior experiences in industry collaboration can enhance the development of alliance capabilities (Rothaermel and Deeds 2006) and they can reduce coordination costs thus improving the performance of exchanges with external partners (Kotha et al. 2013). Unit size was measured based on the total number of members, ranging from 1 for "1 to 5 members" to 5 for "more than 50 members." Finally, technology transfer experience was measured by asking respondents to indicate the number of outward technology transfer projects the unit has completed previously. This experience measure was log transformed for the net effects analysis. Table 2 summarizes information on the construct measures and shows the items for each of the constructs.

\subsection{Data analysis}

We employed a two-step approach to analyze the data and delineate the effect of alliance management capability on technology transfer effectiveness. In the first step, we performed an analysis of net effects using partial least squares (PLS) SEM and the SmartPLS software program (version 2.0; Ringle et al. 2005). PLS-SEM is a variance-based, iterative estimation procedure that focuses on maximization of the variance of the dependent variables explained by the independent variables (Chin 1998). PLS-SEM is especially useful when the research goal is the prediction of a target outcome or the identification of key drivers of an outcome (Hair et al. 2011). Data analysis began with the estimation of the measurement model. After that, we proceeded with an analysis of the structural model. To assess the structural relationships, we first analyzed the overall effect of alliance management capability on technology transfer success, treating alliance management capability as a secondorder construct. We used a hierarchical component model, which created the second-order factor with the indicators of lower-order factors (Wetzels et al. 2009). Next, we re-analyzed the model, treating the managerial routines reflecting alliance management capability as four independent factors that influence technology transfer success. These analyses provided insights into the net effects of alliance management capability on effectiveness of technology transfer both on an overall and a de-compositional level. In the second step, we performed an analysis of configurational effects using fsQCA (Ragin 2008) and the fs/QCA software program (Ragin et al. 2006). FsQCA is a set-theoretic method based on Boolean algebra and can provide insights into configurations of antecedent conditions sufficient for an outcome in question. Following the procedure as suggested by Ragin (2008) and Fiss (2011), the fsQCA proceeded in three stages: calibration of fuzzy sets, construction and refinement of the so-called truth table, and analysis of the truth table.

\subsubsection{Step 1: Analysis of net effects}

Data analysis began with the evaluation of the measurement model (Hair et al. 2011; 2012). The results of this analysis indicated satisfactory levels of composite reliability and average variance extracted for the construct measures; the respective coefficients for all constructs exceeded the threshold values of .6 and .5, respectively (Bagozzi and Yi 1988). 


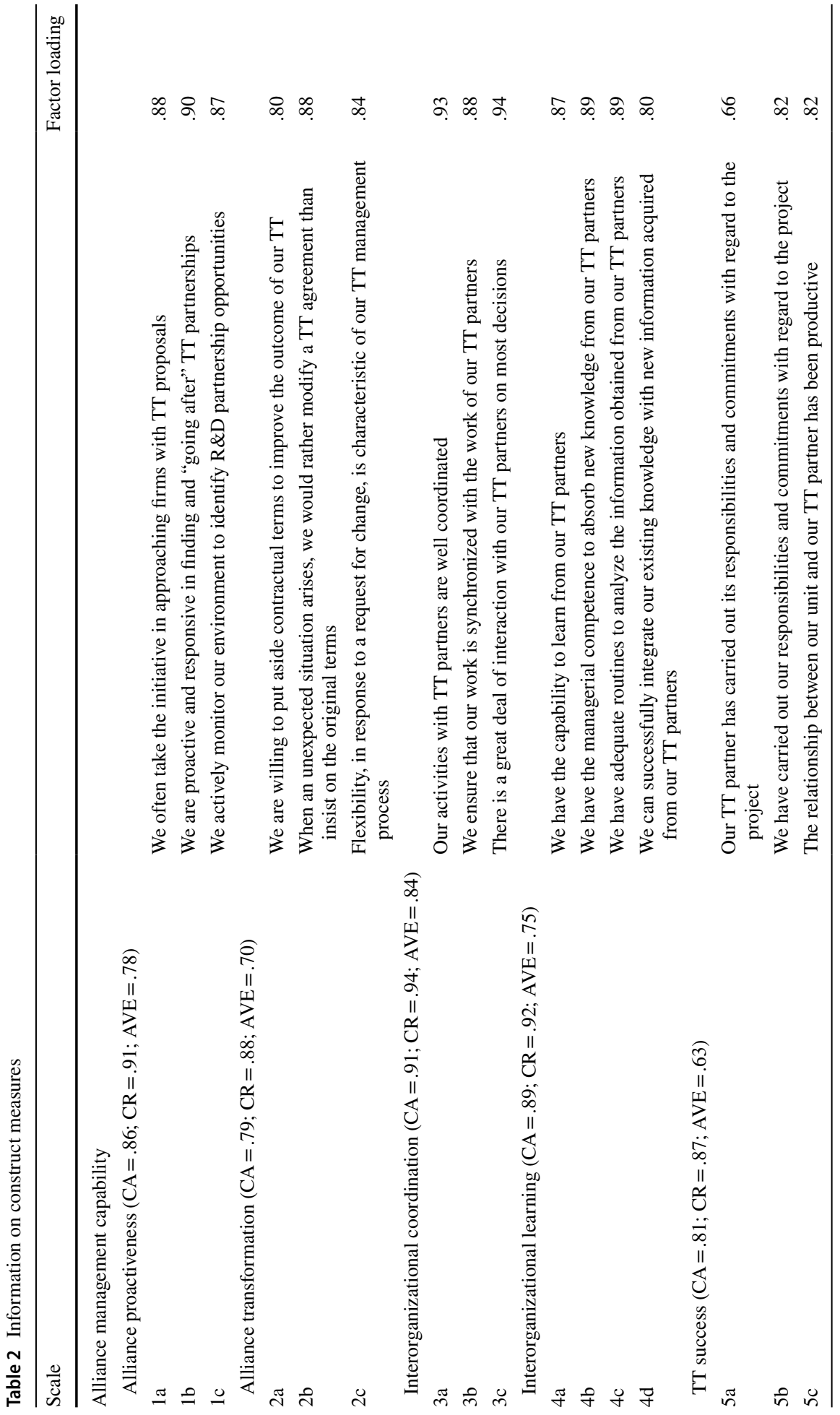




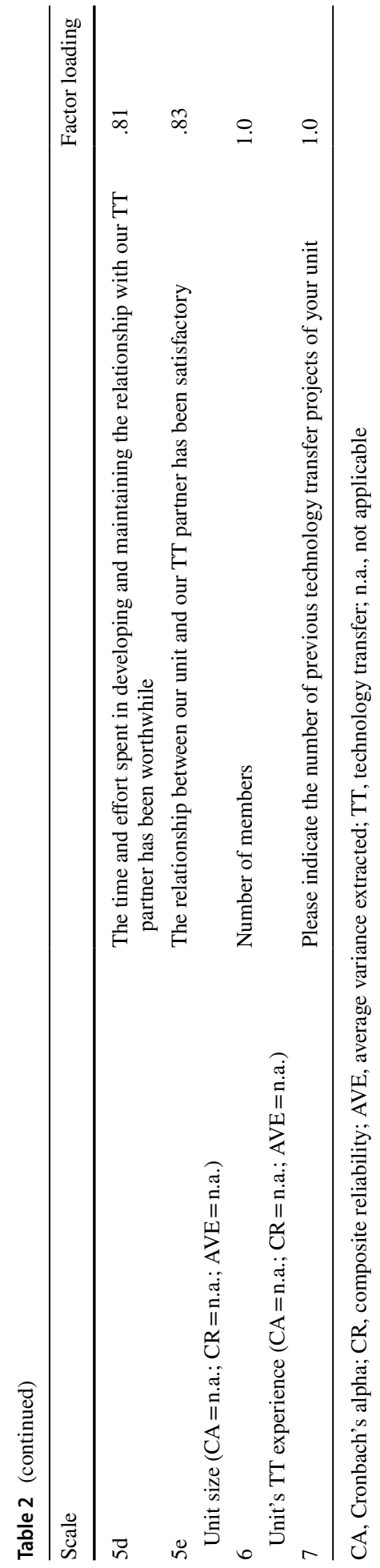

Springer 
All factor loadings were high and significant at the .001 level, which indicates satisfactory convergent validity (Hulland 1999). In addition, the results showed that Cronbach's alpha passed the threshold value of .7 for all constructs (Nunnally 1978). Furthermore, analysis of discriminant validity following the procedure as suggested by Fornell and Larcker (1981) indicated that the average variances extracted for any two factors were greater than the squared correlation between the two factors, thus pointing to satisfactory discriminant validity (see Table 3 ).

To evaluate the structural model(s) and the net effects of alliance management capability (as well as its underlying routines) on technology transfer success, we run two analyses. In each analysis, we evaluated the explained variance of the outcome variable (i.e., $\mathrm{R}^{2}$ ). In addition, we assessed the magnitude, valence, and significance of the path coefficients, and we calculated effect sizes ( $f^{2}$; Cohen 1988) for each of the antecedents. For significance assessments, we performed a nonparametric bootstrapping procedure following Hair et al. (2012) with the analysis settings: 85 cases, 5000 subsamples, and individual sign change.

\subsubsection{Step 2: Analysis of configurational effects}

To complement the insights of the analysis of net effects and to obtain a deeper understanding about what configurations of alliance management routines contribute to successful technology transfer, we run an additional fsQCA. This analysis involved six antecedent conditions (i.e., the four alliance management routines and two organizational characteristics) and one outcome of interest (i.e., technology transfer success). We briefly describe each of the steps of the analysis below.

FsQCA builds on the premise that conditions and the relationships between these conditions are conceivable in terms of set membership and set relations (Fiss 2011). To assess set relations, conditions, that is, antecedent conditions as well as the outcome condition of interest, have to be represented in fuzzy sets, thus requiring calibration. Calibration is the transformation of a construct measure into a fuzzy-set membership score. As a result of calibration, each case in the empirical basis has fuzzy-set scores that indicate the degree of membership of the case in the antecedent sets and the outcome set under analysis. Fuzzyset scores can range between 0 (for full non-membership) to 1 (for full membership). The value .5 denotes the crossover point and reflects the threshold to distinguish between membership in or out of a fuzzy set.

Table 3 Means, standard deviations, and correlations

\begin{tabular}{|c|c|c|c|c|c|c|c|c|c|}
\hline & M & SD & 1 & 2 & 3 & 4 & 5 & 6 & 7 \\
\hline Alliance proactiveness & 3.98 & .91 & .77 & & & & & & \\
\hline Alliance transformation & 4.29 & 69 & .32 & .70 & & & & & \\
\hline Interorganizational coordination & 4.38 & .78 & .37 & .38 & .84 & & & & \\
\hline Interorganizational learning & 4.39 & 67 & .43 & .48 & .53 & .75 & & & \\
\hline TT success & 4.13 & .59 & .23 & .43 & .29 & .36 & .62 & & \\
\hline Unit size & 3.53 & 1.28 & .00 & .00 & .00 & .00 & .00 & - & \\
\hline Unit's TT experience & 52.93 & 131.36 & .06 & .02 & .03 & .00 & .10 & .05 & - \\
\hline
\end{tabular}

M, mean; SD, standard deviation; numbers on the diagonal show the AVE; numbers below the diagonal show the squared correlations; TT, technology transfer 
For calibration, we combined the multiple-item construct measures into average scores and, following Ragin (2008), specified thresholds for full membership in the fuzzy sets, thresholds for full non-membership in the fuzzy sets, and crossover points to structure the calibration. For example, for the set of high alliance proactiveness, we used the scale maximum (i.e., value 5 on a five-point Likert scale) as the threshold for full membership in the set and the scale midpoint (i.e., value 3) as the threshold for full non-membership in the set. Value 4, that is, the halfway mark between the scale maximum and the scale midpoint served as the crossover point. This approach implies that all cases that indicated full agreement with the items for alliance proactiveness were fully in the set of units with high alliance proactiveness, whereas cases that indicated indifference or that reported disagreement with these items (i.e., value 3 or lower) were fully out of the set of highly alliance-proactive units. Cases that have a value higher than 4 ("rather agree") but lower than 5 were more in than out of this set and cases that have a value between 3 and 4 were more out of than in this set. We used the same calibration rules to define the fuzzy sets for the remaining three alliance management routines and for the focal outcome condition of high technology transfer success. To calibrate the set of unit size, we set the threshold for full membership in the set at value 4, the threshold for full non-membership in this set at value 1 , and the crossover point at value 3 . Thus, units with more than 20 members were fully in the set of large units, whereas units with five members or less were fully out of the set of large units. The crossover point corresponds to a unit size of 10 members. For the set of high technology transfer experience, we defined cases with more than 10 previous technology transfer projects to be fully in the set, and cases with only one or no previous technology transfer project to be fully out of the set of experiences units. To calibrate this set, we set the crossover point at value 5. Because cases with fuzzy-set memberships scores of precisely .5 (i.e., the point of most ambiguity) cause difficulties regarding the intersection of fuzzy sets, Ragin (2008) recommends avoiding the use of a precise .5 fuzzy-set membership score for conditions. To address this concern, in line with prior studies (e.g., Fiss 2011), we added a constant of .001 to all conditions with fuzzy-set membership scores smaller than 1 .

After calibration of all fuzzy sets, we created a so-called truth table, which is a data matrix consisting of $2^{\mathrm{k}}$ rows, where $\mathrm{k}$ denotes the number of antecedent conditions (Ragin 2008). The truth table lists all logically possible combinations of the antecedents and shows their extent of empirical representation (Fiss 2011). To perform the fsQCA, the truth table needs refinement based on two primary criteria, that is, frequency and consistency (Ragin 2008). Frequency refers to the extent to which particular combinations of antecedent conditions are empirically represented and focuses on the distribution of empirical cases across the rows of the truth table. The definition of a frequency threshold implies that only those combinations with a minimum level of empirical representation will be part of the analysis. The rationale behind this rule is that configurations with limited or no empirical representation might be attributable to random forces or measurement errors (Ragin and Fiss 2008). Following recommendations in the QCA literature (Greckhamer et al. 2013; Ragin 2008), we set the frequency threshold in our study at value 2 .

Consistency refers to the degree to which the cases that occupy a particular row in the truth table agree in displaying the outcome in question (Ragin 2008). In an analysis of sufficiency, it indicates "how closely a perfect subset relation is approximated" (Ragin 2008, p. 44). The definition of a consistency threshold thus distinguishes configurations that are consistent subsets of the outcome set from those that are not. The QCA literature recommends inspecting dips in consistency scores to identify consistency thresholds and suggests a minimum acceptable consistency level of .8 (Ragin 2008). In addition, QCA studies suggest inspecting values of the proportional reduction in 
inconsistency (PRI) (Misangyi and Acharya 2014) to distinguish between consistent and inconsistent combinations for an outcome. Following this, we set the minimum acceptable level of consistency at .8. Next, and for the configurations passing this threshold value, we inspected PRI scores and set the minimum acceptable level at value 75 (Misangyi and Acharya 2014). The fsQCA solution table presented below reports the resulting actual consistency and PRI values used for the analysis.

Having prepared the truth table for subsequent analysis, we then examined set-subset relations using the Quine-McCluskey algorithm as implemented in the fs/QCA software program (Ragin et al. 2006). The algorithm identifies combinations of antecedents that consistently lead to an outcome by stripping away those factors that are sometimes present and sometimes absent, thus indicating that these factors are no essential parts of a sufficient configuration for the outcome in question (Fiss 2011). The results of a fsQCA show the configurations of antecedents sufficient for an outcome as well as consistency (mentioned above) and coverage scores to evaluate these solutions. Coverage scores help assess the relative empirical importance of configurations for an outcome (Ragin 2008). FsQCA reports an overall solution coverage score for the solution sufficient for the outcome and raw and unique coverage scores for each of the particular configurations that form the overall solution. Raw coverage refers to the extent of overlap between the size of the configuration set and the outcome set relative to the size of the outcome set. Since some cases may be present in several configurations, fsQCA controls for these overlaps and partitions the raw coverage to obtain a particular configuration's unique coverage with the outcome set (Ragin 2008).

Table 4 Results of the net effects analysis

\begin{tabular}{lccc}
\hline Causal factors & \multicolumn{3}{l}{ TT success } \\
\cline { 2 - 4 } & $\beta$ & t-value & $\mathrm{f}^{2}$ \\
\hline Analysis 1 & & & \\
Alliance management capability & .63 & $6.20^{* * *}$ & .75 \\
Unit size & -.02 & .57 & .00 \\
Unit's TT experience & .24 & $2.89 * * *$ & .10 \\
$\mathrm{R}_{\mathrm{TT}}^{2}$ success & .49 & & \\
Analysis 2 & & & .00 \\
Alliance proactiveness & -.06 & .81 & .16 \\
Alliance transformation & .38 & $4.12^{* * * *}$ & .00 \\
Interorganizational coordination & .04 & .44 & .08 \\
Interorganizational learning & .35 & $2.34 * * *$ & .01 \\
Unit size & -.05 & .77 & .15 \\
Unit's TT experience & .29 & $3.36 * * *$ & \\
$\mathrm{R}_{\text {TT success }}^{2}$ & .55 & & \\
\hline
\end{tabular}

$\mathrm{f}^{2}$, effect size; TT, technology transfer

$* * * p<.01 ; * * p<.05 ; * p<.1$ 


\section{Results}

\subsection{Results of the analysis of net effects}

Table 4 shows the results of the two net effects analyses. Alliance management capability, as a higher-order concept, has a significant positive effect on technology transfer success $(\beta=.63, p<.01)$ and achieves a proportion of explained variance of $\mathrm{R}^{2}=.49$. Regarding the effects of the first-order dimensions, the results of the analysis reveal that alliance transformation $(\beta=.38, p<.01)$ and interorganizational learning $(\beta=.35, p<.01)$ have significant positive effects on technology transfer success $\left(\mathrm{R}^{2}=.55\right)$. For the remaining two dimensions, however, the results did not indicate significant effects.

\subsection{Results of the analysis of configurational effects}

Table 5 depicts the results obtained by the fsQCA. We summarize these results using the notation developed by Ragin and Fiss (2008): full circles indicate the presence of a condition, circles with a cross-out indicate the negation of a condition, large circles indicate core conditions, small circles indicate peripheral conditions, and blank spaces indicate that a condition does not matter in a configuration. The fsQCA reveals four configurations sufficient for highly successful technology transfer (i.e., configurations 1 to 4), with two of these configurations having two neutral permutations (i.e., configuration 2: $2 a$ and $2 b$, and configuration $3: 3 \mathrm{a}$ and $3 \mathrm{~b}$ ). The overall solution consistency is .83 , which indicates that the identified configurations represent consistent pathways to successful technology transfer. In addition, the overall solution coverage is .80 , thus indicating that the configurations "explain" a substantial proportion of the outcome set.

Table 5 Results of the configurational effects analysis

\begin{tabular}{|c|c|c|c|c|c|c|}
\hline \multirow[b]{2}{*}{ Antecedent conditions } & \multicolumn{6}{|c|}{ Configurations } \\
\hline & 1 & $2 \mathrm{a}$ & $2 b$ & $3 \mathrm{a}$ & $3 b$ & 4 \\
\hline \multicolumn{7}{|l|}{ Alliance management capability } \\
\hline Alliance proactiveness & & & $\otimes$ & & & \\
\hline Alliance transformation & $\bullet$ & $\bullet$ & $\otimes$ & & & $\bullet$ \\
\hline Interorganizational coordin & - & & & & & 0 \\
\hline Interorganizational learning & & & & & & \\
\hline \multicolumn{7}{|l|}{ Organizational characteristics } \\
\hline \multicolumn{7}{|l|}{ Unit size } \\
\hline \multicolumn{7}{|l|}{ Unit's TT experience } \\
\hline Consistency & .87 & .89 & .92 & .91 & .87 & .89 \\
\hline Raw coverage & .64 & .51 & .14 & .45 & .44 & .43 \\
\hline Unique coverage & .20 & .07 & .01 & .03 & .02 & .01 \\
\hline Overall solution consistency & \multicolumn{6}{|c|}{.83} \\
\hline Overall solution coverage & \multicolumn{6}{|c|}{.80} \\
\hline
\end{tabular}

$=$ presence of an antecedent condition; $\otimes=$ negation of an antecedent condition; big circles $=$ core conditions; small circles $=$ peripheral conditions; blank space $=$ absence of an antecedent condition; analysis thresholds: frequency $=2$, consistency $=.89$, PRI score $=.76$; intermediate and parsimonious solutions; $\mathrm{TT}=$ technology transfer 
Configuration 1 includes the presence of all four alliance management routines. High alliance proactiveness is a core condition and alliance transformation, interorganizational coordination, and interorganizational learning are peripheral conditions. In configuration 1, unit size and an academic unit's prior experience with technology transfers have subordinate roles as indicated by the blank spaces. Thus, the development of a strong alliance management capability in academic units is a sufficient pathway to achieve successful technology transfer.

Configuration 2 has two permutations (i.e., $2 \mathrm{a}$ and $2 \mathrm{~b}$ ). Solution $2 \mathrm{a}$ involves the presence of high alliance transformation in combination with the presence of high interorganizational coordination, interorganizational learning, unit size, and prior experience. In this configuration, interorganizational learning and prior experience are core conditions and the remaining conditions are peripheral factors. In addition, alliance proactiveness has a subordinate role. Solution 2a, thus, involves large and technology transfer-experienced academic units with established routines for transformation, coordination of activities, and integration of knowledge. In contrast to solution $2 \mathrm{a}$, solution $2 \mathrm{~b}$ reflects a configuration including the negation of high alliance proactiveness, the negation of high alliance transformation, the presence of high interorganizational coordination, the presence of high interorganizational learning, the negation of a large unit size, and the presence of high prior experience with technology transfers. Again, the presence of high interorganizational learning and the presence of prior experience with technology transfers are core conditions; the remaining elements of this solution are peripheral factors. This solution covers small academic units with prior technology transfer experience. These units are not alliance-proactive and they show a lower level of flexibility when it comes to adaptation requirements. However, these units have established coordination and learning mechanisms, thus achieving effective technology transfers.

As the results in Table 5 reveal, configuration 3 has two neutral permutations as well (i.e., solutions $3 \mathrm{a}$ and $3 \mathrm{~b}$ ). Solution $3 \mathrm{a}$ involves academic units with a high alliance proactiveness, high alliance transformation, high interorganizational coordination, large unit size, and rich prior experience in executing technology transfers. In this solution, the presence of high alliance proactiveness, interorganizational learning, and prior experience are core conditions, whereas the presence of high alliance transformation and large unit size are peripheral conditions. Interorganizational coordination has a minor role. Solution $3 \mathrm{~b}$ reveals a similar configuration of factors. However, it differs from solution 3a in that the presence of high interorganizational coordination is an element of solution $3 \mathrm{~b}$ and the presence of high alliance transformation has a subordinate role as indicated by the blank space.

Finally, configuration 4 involves a combination of factors including the presence of high alliance proactiveness, alliance transformation, interorganizational learning, large unit size, and high prior experience with technology transfers. In configuration 4, the presence of high alliance proactiveness is a core condition. Interorganizational learning has a subordinate role in this configural statement. Thus, configuration 4 includes large academic units with prior experience in executing technology transfers and established routines for sensing potentially relevant partners, adjusting ongoing technology transfer projects, and coordinating activities.

\section{Discussion}

\subsection{Theoretical contributions}

Commercialization of technology by universities has emerged as an important source for firms to acquire technological expertise and know-how (e.g., Shane 2002). The success 
of university-based knowledge commercialization depends on academic units' entrepreneurial orientation and their capability to systematically manage alliances with the industry to enhance outward technology transfer (Etzkowitz 2004; Friedman and Silberman 2003; Perkmann et al. 2011). Today, academic units frequently act as "quasi-firms": they adopt commercial logics and implement routines to govern interorganizational relationships with external partners and they develop their own business models (Ambos et al. 2008; Miller et al. 2014; Tartari and Breschi 2012). Based on this premise, we aimed at improving the knowledge on university-industry technology transfer through empirical examination of alliance management capability on the side of academic units and its implications for technology transfer success. Our research thus responds to recent research that advocates revision of the traditional model of university technology transfer and that emphasizes the need for developing alternative perspectives on technology transfer to better capture its complex and multifaceted nature (Bradley et al. 2013).

Drawing on prior alliance management research (Anand and Khanna 2000; Leischnig et al. 2014; Schilke and Goerzen 2010), we conceptualize alliance management capability as a concept consisting of four routines (i.e., alliance proactiveness, alliance transformation, interorganizational coordination, and interorganizational learning) and examine its effects on technology transfer success, using a mixed-method approach that includes analyses of net effects and the analysis of configurational effects. The findings of our study contribute to the extant body of work on university-industry collaboration by demonstrating that the capacity of academic units to govern exchange processes with industry partners does matter and increases technology transfer success. Our study highlights alliance management capability as an important feature of academic units as transfer agents and it is among the few to provide insights into high-order and first-order net effects of alliance management capability on technology transfer success, thus deepening the understanding of performance drivers in university-industry collaborations.

As the analysis of net effects has shown, alliance management capability exerts a significant positive effect on technology transfer success. A subsequent analysis of the net effects of specific alliance management routines further indicates that especially transformation and learning routines have significant positive effects on technology transfer effectiveness. These insights complement those of prior studies which examined technology transfer processes from the transferees' point of view (e.g., Leischnig et al. 2014). To further supplement the findings, we then examined what combinations of alliance management routines are sufficient for an effective technology transfer, thus contributing to the literature by considering multiple conjunctural causality (Ragin 2008) and the interconnected structures of alliance management routines and organizational characteristics (herein unit size and prior technology transfer experience). We performed a configurational effects analysis using fsQCA and identified four alternative configurations of factors that indicate successful technology transfer activity. These configurations differ in their particular composition, but they represent consistently sufficient, equifinal pathways to the outcome under investigation. Knowledge of the configurations provides vision for complementarity and substitution effects among alliance management routines and organizational characteristics and offers design choices regarding how to configure alliance management practices to achieve successful technology transfers. For example, configuration 1 shown in Table 5 reveals that the presence of all four alliance management routines constitutes a sufficient pathway for high technology transfer success, irrespective of academic units' size or technology transfer experience. Thus, well-established managerial routines to manage relationships with external partners appear to produce context independence (in regard to unit size and experience), which implies that rather inexperienced as well as experienced, and 
rather small as well as large units can achieve high technology transfer effectiveness when a strong alliance management capability exists. In addition, a comparison of solutions $3 \mathrm{a}$ and $3 \mathrm{~b}$ indicates a substitution effect between alliance transformation and interorganizational coordination. Configuration $3 \mathrm{a}$ indicates that a well-established alliance transformation routine allows for technology transfer success regardless of whether an academic unit has implemented a strong interorganizational coordination mechanism or not. In contrast, configuration $3 \mathrm{~b}$ indicates the opposite and shows that in the presence of well-established interorganizational coordination mechanisms, alliance transformation routines may be present or not. Noteworthy, either of these two configurations encompasses large units with experience in technology transfer projects and with strong alliance proactiveness and interorganizational learning routines.

In summary, the insights obtained by our study advance the current knowledge on university-industry collaboration by focusing on academic units as important players in technology transfer processes and by further illuminating and clarifying the role and effects of academic units' alliance management capability as an antecedent of technology transfer success. Our research thus contributes to the literature on entrepreneurial universities (e.g., Etzkowitz 2003, 2004) and especially academic-industry collaboration as a mechanism of technology transfer that has been insufficiently reflected by the traditional model of technology transfer (Bradley et al. 2013).

\subsection{Managerial implications}

The findings of this study have several implications for different stakeholders, such as researchers and academic units, technology transfer offices (TTOs), university administration, and policy makers. With regard to researchers and academic units, we underline the importance of developing and maintaining alliance management capability. To build alliance proactiveness, it is important that researchers understand the environment of their field and that they are able to identify market requirements and new opportunities to commercialize academic knowledge and technology. Notably, researchers should select technology transfer partners carefully: university-industry collaborations should enable researchers to benefit from resources external partners offer (e.g., novel insights, impulses for research, access to superior research infrastructure or financial support). At the same time, however, such collaborations should not constrain their individual academic freedom to pursue research not only for the sake of marketability and potential revenues, but also for advancing scientific knowledge (Tartari and Breschi 2012). Sufficient alliance transformation can be ensured if academic units are open and flexible to structural changes in technology transfer relationships with firms. Additionally to individual predispositions, the spirit and norms within academic units are decisive for fostering an open-minded atmosphere that facilitates collaborations across organizational boundaries. By formulating objectives and rules for coordinating interactions, academic units gain opportunities to efficiently manage their relationships with partner firms. Such rules could, for instance, cover ways of communication, meeting schedules and work plans, definition of managerial authorities, or conflict solving strategies. Interorganizational learning can be enhanced by gathering, analyzing, and incorporating information obtained from technology transfer partners and by absorbing and integrating external knowledge. One way to accomplish interorganizational learning is an increased mobility of researchers between universities and firms in such a way that face-to-face interactions and intensive exchanges take place that support 
the transfer of tacit knowledge, increase social capital between the interactants, and enable mutual information acquisition and learning (Schartinger et al. 2002).

The development and implementation of such routines may require redefinition of existing task portfolios and reallocation of resources. Since academic units typically differ in resource endowments, the configurations obtained by the fsQCA may serve as starting points to assess the existing features of an academic unit (e.g., in terms of size, prior technology transfer experience, and the established repertoire of alliance management routines) and to develop strategies for routinization and capability leverage. Universities could support the development of alliance management capability by creating an environment that stimulates and fosters the development and implementation of such capabilities. This holds especially for students as parts of research projects and prospective interactants in university-industry collaborations. Students would benefit from courses, workshops, case studies, or personal training measures, which develop and broaden their understanding of technology transfer processes with the industry and help them developing their skills to sense opportunities and identify transfer partners, adopt transfer relationships, coordinate university-industry collaborations, and gather, analyze and integrate knowledge from such collaborations. This would not only enrich students' curriculum, their educational and career opportunities, it would also support universities in accomplishing their "third mission."

In addition, TTOs at universities may broaden and enrich their tasks and services. University TTOs link academia and industries to support technology transfers and the commercialization of academic knowledge. Traditionally, they are installed to assist researchers in administrative issues concerning inventions and the protection of intellectual property. However, defining transfer offices as a university service provider, they could create additional benefits by serving as advisors for researchers regarding how to establish successful alliances with firms and how to appropriately configure alliance management capabilities, depending on characteristics of academic units, such as age, experience in technology transfer, and others. TTOs and industry-university cooperative research centers might serve as in-house consultancies and offer management programs to train academics and enhance the transformation of academic institutions into what is considered as an "entrepreneurial university" (Etzkowitz 2004). Such training programs may involve senior researchers with extended experience in industry collaboration or external experts with industry background. By so doing, universities could enhance the development of entrepreneurial competencies among academics, which may contribute to the application of university research in business practice. As the preceding implies, TTOs themselves should hire individuals with both research and industry backgrounds and/or experiences in technology transfer with the industry in order to sufficiently support outward technology transfers.

With regard to policy makers, the findings of our study underline the need for a change in university practices and structures to comply with challenges of managing technology transfer relationships with the industry. As Perkmann et al. (2013) note, it is important to strengthen individual researchers' skills to manage university-industry collaborations in their various forms and manifestations as well as to offer them discretionary power and flexibility to collaborate with external partners. To enhance effective technology transfers and to design purposeful frameworks, evaluation, and incentive systems, policy-makers should have an eye not only on the sheer volume of university-industry collaboration, revenues or third-party funding, but also on the quality of technology transfer relationships (Perkmann et al. 2013; Tartari and Breschi 2012). Currently, we observe a somewhat one-sided debate on the relevance and effectiveness of the "entrepreneurial university." Undoubtedly, universities play a decisive role for a society's well-being as creators of knowledge and enabler of innovations. Nevertheless, the "third mission" may have not only 
positive but also detrimental effects on a university's original mission, that is, teaching and conducting fundamental research. So far, having only spurious evidence on the outcomes of academic engagement, we need to know more about the impact of university-industry collaborations on universities' performance and challenges for an organizational change (Perkmann et al. 2013).

Acknowledgements We thank Thomas Ritter and Oliver Schilke for comments on a previous draft of this paper and Stefanie Lohmann for her support in collecting the data. In addition, we thank the German Research Foundation for supporting the research project.

Funding This study was funded by the German Research Foundation (Grant Number EN 496/5-1).

\section{Compliance with ethical standards}

Conflict of interest The authors declare that they have no conflict of interest.

Open Access This article is distributed under the terms of the Creative Commons Attribution 4.0 International License (http://creativecommons.org/licenses/by/4.0/), which permits unrestricted use, distribution, and reproduction in any medium, provided you give appropriate credit to the original author(s) and the source, provide a link to the Creative Commons license, and indicate if changes were made.

\section{References}

Ambos, T. C., Mäkelä, K., Birkinshaw, J., \& D’Este, P. (2008). When does university research get commercialized? Creating ambidexterity in research institutions. Journal of Management Studies, 45(8), 1424-1447.

Anand, B. N., \& Khanna, T. (2000). Do firms learn to create value? The case of alliances. Strategic Management Journal, 21(3), 295-315.

Armstrong, J. S., \& Overton, T. S. (1977). Estimating nonresponse bias in mail surveys. Journal of Marketing Research, 14(3), 396-402.

Azagra-Caro, J. M., Barberá-Tomás, D., Edwards-Schachter, M., \& Tur, E. M. (2017). Dynamic interactions between university-industry knowledge transfer channels: A case study of the most highly cited academic patent. Research Policy, 46(2), 463-474.

Bagozzi, R. P., \& Yi, Y. (1988). On the evaluation of structural equation models. Journal of the Academy of Marketing Science, 16(1), 74-94.

Bozeman, B. (2000). Technology transfer and public policy: A review of research and theory. Research Policy, 29(4), 627-655.

Bradley, S. R., Hayter, C. S., \& Link, A. N. (2013). Models and methods of university technology transfer. Foundations and Trends ${ }^{\circledR}$ in Entrepreneurship, 9(6), 571-650.

Bruneel, J., D'Este, P., \& Salter, A. (2010). Investigating the factors that diminish the barriers to universityindustry collaboration. Research Policy, 39(7), 858-868.

Bucklin, L. P., \& Sengupta, S. (1993). Organizing successful co-marketing alliances. Journal of Marketing, $57(2), 32-46$.

Chandran, V. G. R., Hayter, C. S., \& Strong, D. R. (2015). Personal strategic alliances: Enhancing the scientific and technological contributions of university faculty in Malaysia. Economics of Innovation and New Technology, 24(5), 421-435.

Chin, W. W. (1998). The partial least squares approach to structural equation modeling. In G. A. Marcoulides (Ed.), Modern methods for business research (pp. 295-358). Mahwah, NJ: Lawrence Erlbaum Associates.

Cohen, J. (1988). Statistical power analysis for the behavioral sciences. Mahwah, NJ: Lawrence Erlbaum Associates.

Cyert, R. M., \& Goodman, P. S. (1997). Creating effective university-industry alliances: An organizational learning perspective. Organizational Dynamics, 25(4), 45-57.

D'Este, P., \& Patel, P. (2007). University-industry linkages in the UK: What are the factors underlying the variety of interactions with industry? Research Policy, 36(9), 1295-1313. 
D’Este, P., \& Perkmann, M. (2011). Why do academics engage with industry? The entrepreneurial university and individual motivations. Journal of Technology Transfer, 36(3), 316-339.

Dyer, J. H., \& Singh, H. (1998). The relational view: Cooperative strategy and sources of interorganizational competitive advantage. Academy of Management Review, 23(4), 660-679.

Etzkowitz, H. (1998). The norms of entrepreneurial science: Cognitive effects of the new univer-sity-industry linkages. Research Policy, 27(8), 823-833.

Etzkowitz, H. (2003). Research groups as 'quasi-firms': The invention of the entrepreneurial university. Research Policy, 32(1), 109-121.

Etzkowitz, H. (2004). The evolution of the entrepreneurial university. International Journal of Technology and Globalisation, 1(1), 64-77.

Etzkowitz, H., Webster, A., Gebhardt, C., \& Terra, B. R. C. (2000). The future of the university and the university of the future: Evolution of ivory tower to entrepreneurial paradigm. Research Policy, 29(2), 313-330.

European Commission. (2011). What is Horizon 2020? Horizon 2020. https://ec.europa.eu/programmes/ horizon2020/en/what-horizon-2020. Accessed October 1, 2017.

Fiss, P. C. (2011). Building better causal theories: A fuzzy set approach to typologies in organization research. Academy of Management Journal, 54(2), 393-420.

Fornell, C., \& Larcker, D. F. (1981). Evaluating structural equation models with unobservable variables and measurement error. Journal of Marketing Research, 18(1), 39-50.

Friedman, J., \& Silberman, J. (2003). University technology transfer: Do incentives, management, and location matter? Journal of Technology Transfer, 28(1), 17-30.

Geigenmüller, A., \& Leischnig, A. (2017). A configurational perspective on alliance management capabilities. In T. K. Das (Ed.), Managing alliance portfolios and networks. Research in strategic alliances (pp. 71-90). Charlotte, NC: Information Age Publishing.

Göktepe-Hulten, D., \& Mahagaonkar, P. (2010). Inventing and patenting activities of scientists: In the expectation of money or reputation? Journal of Technology Transfer, 35(4), 401-423.

Greckhamer, T., Misangyi, V. F., \& Fiss, P. C. (2013). The two QCAs: From a small-N to a large-N set theoretic approach. In P. C. Fiss, B. Cambré, \& A. Marx (Eds.), Configurational theory and methods in organizational research. Research in the sociology of organizations (pp. 49-75). Bingley: Emerald.

Hair, J. F., Ringle, C. M., \& Sarstedt, M. (2011). PLS-SEM: Indeed a silver bullet. Journal of Marketing Theory \& Practice, 19(2), 139-152.

Hair, J. F., Sarstedt, M., Ringle, C. M., \& Mena, J. A. (2012). An assessment of the use of partial least squares structural equation modeling in marketing research. Journal of the Academy of Marketing Science, 40(3), 414-433.

Heide, J. B., \& John, G. (1990). Alliances in industrial purchasing: The determinants of joint action in buyer-supplier relationships. Journal of Marketing Research, 27(1), 24-36.

Helfat, C. E., Finkelstein, S., Mitchell, W., Peteraf, M. A., Singh, H., Teece, D. J., et al. (2007). Dynamic capabilities: Understanding strategic change in organizations. Malden, MA: Blackwell.

Hulland, J. (1999). Use of partial least squares (PLS) in strategic management research: A review of four recent studies. Strategic Management Journal, 20(2), 195-204.

Jain, S., George, G., \& Maltarich, M. (2009). Academics or entrepreneurs? Investigating role identity modification of university scientists involved in commercialization activity. Research Policy, 38(6), 922-935.

Kale, P., Dyer, J. H., \& Singh, H. (2002). Alliance capability, stock market response, and long-term alliance success: The role of the alliance function. Strategic Management Journal, 23(8), 747-767.

Kale, P., \& Singh, H. (2007). Building firm capabilities through learning: The role of the alliance learning process in alliance capability and firm-level alliance success. Strategic Management Journal, 28(10), 981-1000.

Kotha, R., George, G., \& Srikanth, K. (2013). Bridging the mutual knowledge gap: Coordination and the commercialization of university science. Academy of Management Journal, 56(2), 498-524.

Kumar, R., \& Nti, K. O. (1998). Differential learning and interaction in alliance dynamics: A process and outcome discrepancy model. Organization Science, 9(3), 356-367.

Lambe, C. J., Spekman, R. E., \& Hunt, S. D. (2002). Alliance competence, resources, and alliance success: Conceptualization, measurement, and initial test. Journal of the Academy of Marketing Science, 30(2), $141-158$.

Lane, P. J., \& Lubatkin, M. (1998). Relative absorptive capacity and interorganizational learning. Strategic Management Journal, 19(5), 461-477.

Leischnig, A., Geigenmueller, A., \& Lohmann, S. (2014). On the role of alliance management capability, organizational compatibility, and interaction quality in interorganizational technology transfer. Journal of Business Research, 67(6), 1049-1057. 
Leischnig, A., \& Geigenmüller, A. (2018). When does alliance proactiveness matter to market performance? A comparative case analysis. Industrial Marketing Management. https://doi.org/10.1016/j.indma rman.2017.09.025.

Leischnig, A., Henneberg, S. C., \& Thornton, S. C. (2016). Net versus combinatory effects of firm and industry antecedents of sales growth. Journal of Business Research, 69(9), 3576-3583.

Lumpkin, G. T., \& Dess, G. G. (1996). Clarifying the entrepreneurial orientation construct and linking it to performance. Academy of Management Review, 21(1), 135-172.

Meyer, M. (2003). Academic entrepreneurs or entrepreneurial academics? Research-based ventures and public support mechanisms. R\&D Management, 33(2), 107-115.

Meyer-Krahmer, F., \& Schmoch, U. (1998). Science-based technologies: University-industry interactions in four fields. Research Policy, 27(8), 835-851.

Miller, K., McAdam, M., \& McAdam, R. (2014). The changing university business model: A stakeholder perspective. R\&D Management, 44(3), 265-287.

Misangyi, V. F., \& Acharya, A. G. (2014). Substitutes or complements? A configurational examination of corporate governance mechanisms. Academy of Management Journal, 57(6), 1681-1705.

Nunnally, J. C. (1978). Psychometric theory. New York, NY: McGraw-Hill Book Company.

OECD. (2010). Innovation to strengthen growth and address global and social challenges. Key findings. Ministerial report on the OECD Innovation Strategy. http://eur-lex.europa.eu/legal-content/ EN/TXT/PDF/?uri=CELEX:52011DC0808\&from=EN. Accessed 01 Oct 2017.

Pateli, A., \& Lioukas, S. (2012). Antecedents to value creation and value appropriation outcomes of strategic alliances. In T. K. Das (Ed.), Management dynamics in strategic alliances. Research in strategic alliances (pp. 53-72). Charlotte, NC: Information Age Publishing.

Perkmann, M. (2015). University-industry relations. In D. B. Audretsch, C. S. Hayter, \& A. N. Link (Eds.), Concise guide to entrepreneurship, technology and innovation (pp. 227-233). Cheltenham: Edward Elgar Publishing.

Perkmann, M., Neely, A., \& Walsh, K. (2011). How should firms evaluate success in university-industry alliances? A performance measurement system. R\&D Management, 41(2), 202-216.

Perkmann, M., Tartari, V., McKelvey, M., Autio, E., Broström, A., D’Este, P., et al. (2013). Academic engagement and commercialisation: A review of the literature on university-industry relations. Research Policy, 42(2), 423-442.

Perkmann, M., \& Walsh, K. (2007). University-industry relationships and open innovation: Towards a research agenda. International Journal of Management Reviews, 9(4), 259-280.

Perkmann, M., \& Walsh, K. (2008). Engaging the scholar: Three types of academic consulting and their impact on universities and industry. Research Policy, 37(10), 1884-1891.

Ragin, C. C. (2008). Redesigning social inquiry: Fuzzy sets and beyond. Chicago, IL: University of Chicago Press.

Ragin, C. C., Drass, K. A., \& Davey, S. (2006). Fuzzy set/qualitative comparative analysis. www.fsqca .com. Accessed 01 Oct 2017.

Ragin, C. C., \& Fiss, P. C. (2008). Net effects analysis versus configurational analysis: An empirical demonstration. In C. C. Ragin (Ed.), Redesigning social inquiry: Fuzzy sets and beyond (pp. 190212). Chicago, IL: University of Chicago Press.

Reuer, J., \& Zollo, M. (2000). Managing governance adaptations in strategic alliances. European Management Journal, 18(2), 164-172.

Ringle, C. M., Wende, S., \& Will, A. (2005). SmartPLS 2.0. M3. Hamburg: SmartPLS. http://www. smartpls.de. Accessed 01 Oct 2017.

Rothaermel, F. T., \& Deeds, D. L. (2006). Alliance type, alliance experience and alliance management capability in high-technology ventures. Journal of Business Venturing, 21(4), 429-460.

Sarkar, M. B., Echambadi, R. A. J., \& Harrison, J. S. (2001). Alliance entrepreneurship and firm market performance. Strategic Management Journal, 22(6-7), 701-711.

Schartinger, D., Rammer, C., Fischer, M. M., \& Fröhlich, J. (2002). Knowledge interactions between universities and industry in Austria: Sectoral patterns and determinants. Research Policy, 31(3), $303-328$.

Schilke, O. (2014). On the contingent value of dynamic capabilities for competitive advantage: The nonlinear moderating effect of environmental dynamism. Strategic Management Journal, 35(2), 179-203.

Schilke, O., \& Goerzen, A. (2010). Alliance management capability: An investigation of the construct and its measurement. Journal of Management, 36(5), 1192-1219.

Schoenecker, T. S., Myers, D. D., \& Schmidt, P. (1989). Technology transfer at land-grant universities. Journal of Technology Transfer, 14(2), 28-32.

Schreiner, M., Kale, P., \& Corsten, D. (2009). What really is alliance management capability and how does it impact alliance outcomes and success? Strategic Management Journal, 30(13), 1395-1419. 
Shane, S. (2002). Selling university technology: Patterns from MIT. Management Science, 48(1), $122-137$.

Souder, W. E., Nashar, A. S., \& Padmanabhan, V. (1990). A guide to the best technology-transfer practices. Journal of Technology Transfer, 15(1), 5-16.

Tartari, V., \& Breschi, S. (2012). Set them free: Scientists' evaluations of the benefits and costs of university-industry research collaboration. Industrial and Corporate Change, 21(5), 1117-1147.

Van de Ven, A. H. (1976). On the nature, formation, and maintenance of relations among organizations. Academy of Management Review, 1(4), 24-36.

Villani, E., Rasmussen, E., \& Grimalsi, R. (2017). How intermediary organizations facilitate universityindustry technology transfer: A proximity approach. Technological Forecasting and Social Change, $114,86-102$.

Wang, Y., \& Rajagopalan, N. (2015). Alliance capabilities: Review and research agenda. Journal of Management, 41(1), 236-260.

Wetzels, M., Odekerken-Schröder, G., \& Van Oppen, C. (2009). Using PLS path modeling for assessing hierarchical construct models: Guidelines and empirical illustration. MIS Quarterly, 33(1), 177-195.

Woodside, A. G. (2013). Moving beyond multiple regression analysis to algorithms: Calling for adoption of a paradigm shift from symmetric to asymmetric thinking in data analysis and crafting theory. Journal of Business Research, 66(4), 463-472.

Woodside, A. G. (2014). Embrace • perform • model: Complexity theory, contrarian case analysis, and multiple realities. Journal of Business Research, 67(12), 2495-2503. 